\title{
CHALLENGES TO VIETNAMESE FIRMS IN THE WORLD GARMENT AND TEXTILE VALUE CHAIN, AND THE IMPLICATIONS FOR
} ALLEVIATING POVERTY

\author{
Khalid Nadvi and Fohn Thoburn \\ with \\ Bui Tat Thang, Nguyen Thi Thanh Ha, Nguyen Thi Hoa and Dao Hong Le
}

\begin{abstract}
The global garment and textile industries face changing international trade regimes, concerns with labour standards, new competitors and forms of competition. These challenges have a differentiated impact on developing-country producers and workers. One potential 'winner' is Vietnam. This paper uses a global value-chain framework to analyse the Vietnamese experience. It maps Vietnam's changing position in the global industry, and probes ties between Vietnamese firms and global buyers. It explores links within the Vietnamese garment and textiles sectors, and considers the impact of global challenges on Vietnamese firms and workers. This helps distinguish who are the potential 'winners' and 'losers'.
\end{abstract}

Keywords Vietnam, garments, textiles, exports, poverty, value chains.

JEL classifications F14, F23, L67.

\section{INTRODUGTION}

Vietnam has emerged as one of the global success stories of the past decade. Much of this has been premised on a vigorous and successful export-led growth strategy that emerged from the doi moi ('renovation') reforms of the late 1980s. This has required, as the draft development strategy to 2010 states, '. . . a shift in investment toward labour intensive manufacturing activities in general and a shift to manufactured exports in particular' (World Bank Vietnam 2000: 12). The export-led agenda remains at the heart of the policy agenda, as stated recently in the Comprehensive Poverty Reduction and Growth Strategy for Vietnam, which specifies the need to 'continue the open-door policy and actively integrate into the international economy for development' (CPRGS 2002: 60). The process of opening up to the global economy has also involved considerable reforms of its trade regime, although levels of import protection remain high. 
Textiles and garments are an important element of Vietnam's export-led growth policy, currently accounting for about half of the country's manufactured exports. Under the ambitious strategy for the development of the textile and garment industry announced in 1998, and elaborated in April 2001 (Bui 2001), export earnings from textiles and garments are planned to more than quadruple between 2000 and 2010, and employment nearly to triple. This has been, and remains, a significant challenge. Until recently Vietnam was excluded from the largest global garments market in the United States, while it had to reorient its textile and garments exports following the collapse of its major markets in the former USSR and Eastern Europe at the end of the 1980s and early 1990s (Hill 2000).

Vietnamese garment and textiles producers have not only had to adjust to domestic trade liberalization but have also had to prepare themselves for changing global competition. The 'new' competition that marks the global textiles and garment sector is shaped by four distinct features. First, the impending phase out of the Multi-Fibre Arrangement (MFA), the regime governing international trade in textiles and clothing. Second, competition from China. Third, pressures to meet international labour and environmental standards. Fourth, demands from global buyers for cheaper products, higher quality and shorter lead times. These challenges place the garment and textiles industries in many developing countries under severe pressure, with significant consequences for firms and workers.

An earlier paper (Nadvi and Thoburn 2004) documented how Vietnamese firms have inserted themselves into the global garment and textile value chain. The present paper draws on evidence from global buyers and local producers to consider how Vietnamese firms are responding to these new challenges. Section 2 briefly reviews the leading global challenges facing the garment and textiles industry. Section 3 gives an overview of Vietnam's garment and textiles industry, and section 4 assesses how Vietnamese firms face the global challenges. Section 5 , in conclusion, assesses winners and losers amongst firms and workers.

\section{GLOBAL GHALlENGES IN GARMENTS AND TEXTILES}

Textiles and clothing are some of the most regulated traded sectors in the world. They have remained so despite the liberalization efforts of the GATT Uruguay Round. The trade regimes responsible for this are the 1974 Multi-Fibre Arrangement and 1994 Agreement on Textiles and Clothing (Spinanger 1999). The MFA was an explicit attempt to protect developed country producers by restricting exports of textiles and clothing from developing to industrialized countries. It sought to provide temporary protection to developed country firms to undertake the changes necessary to compete against lower-cost producers from developing countries. In practice, the MFA has not only provided an effective framework for extending the protected position of developed country garment manufacturers, it has also given some developing countries preferential quota access to leading markets. The Agreement on Textiles and Clothing (ATC) intended to bring textiles 
and clothing within the ambit of WTO rules by abolishing all MFA quotas by the end of 2004. This was to be done in four stages over a period of ten years, to allow those countries affected by the MFA (both importers and exporters) to take steps to adjust to a new 'free-trade' environment. The ATC clearly stipulated that there would be no retreat from this time frame.

Many developing countries benefited from the MFA, building a thriving clothing industry thanks to the distortions it introduced. Leading garment exporters that were quota restricted (such as Korea and Hong Kong) promoted an export clothing industry in quota-free countries as one channel to jump their own quotas. Countries that built an export garment industry on these distortions, Bangladesh for example, clearly fear the MFA phase out and its consequences for the competitiveness of their clothing industry. These fears, and the continuing protectionist interests of garment producers in the North (the US for example still maintains a large garment manufacturing sector), raise doubts on whether the global clothing and textiles trade will see the kind of liberalization envisaged within the ATC (Spinanger 1999; Edwards 2003). Nevertheless, the MFA phase out, while it could lead to regional and bilateral trade agreements, promises challenges and opportunities for many developing countries.

A further, trade-associated, challenge for low-income garment exporters is competition from China. China is the major player in the garment industry today. It accounted for 18 per cent of total global trade in garments in 2000, up from 9 per cent in 1990 (WTO 2002). It is the largest supplier to the EU and Japan, and the second largest (after Mexico) to the US market where it is severely restricted by the MFA. The phase out of the MFA and China's accession to the WTO are likely to enhance China's position in the US and EU markets. China's potential dominance is reflected in its nearly 75 per cent market share of the liberalized Japanese clothing market. In contrast, its share of the US clothing market is around 13 per cent, and in the EU just under 10 per cent. ${ }^{1}$ China's ascendancy poses a challenge for the export garment industries in other developing countries. Chinese dominance is not, however, a foregone conclusion. Trade restrictions will continue (albeit diminishing) on China even after the MFA phase out, Chinese labour costs are rising and global buyers are nervous of relying solely on Chinese producers. Nevertheless, Chinese competition calls for upgrading by other garment and textiles manufacturers, to raise efficiency and produce higher value-added items.

An additional set of trade-related challenges for T\&G firms supplying global markets comes from pressures to meet global process standards. These include standards on labour conditions, environmental impact, quality assurance as well as wider social and ethical concerns in production. They reflect an enhanced interest with how production and delivery take place as much as with what product or service is provided. For many countries and regions, such standards have become either part of the formal 'rules' governing international trade or a necessary 'voluntary' requirement to access markets. Compliance concerns, particularly with global labour and ethical standards, is especially marked in the textiles and 
garments industry. Such standards are also being driven by a diverse set of drivers, including various international public and private actors, from consumer groups, the corporate sector to local and global NGOs, alongside national and international public sector bodies. Compliance can potentially offer developing-country producers a basis for upgrading. It also raises possibilities of changing the ways in which such producers are inserted into global markets. One hope is that it strengthens the position of developing-country firms in more demanding markets. Global standards can also restrict market access, by raising costs. Despite these concerns, compliance with labour, environmental and social standards have emerged as a key factor in the selecting suppliers by leading brand-name global buyers. Credible and independently monitored certification against global standards offers buyers a basis for offsetting commercial risks. Thus, local garment producers increasingly have to meet buyers' codes of conduct as well as sector-specific and cross-sector standards.

Finally, developing-country $T \& G$ firms face challenges from global garment retailers, to improve quality, reduce costs and shorten production lead times. As Gereffi (1999) has shown, the global garment industry is organized by international retailers, especially leading brand names in the US and the EU. Retailers are themselves heterogeneous. They include independent stores (important in parts of Europe, such as Italy, but less significant in the US and UK), specialist multiples (that only sell garments under their own brand names), department stores (that sell garments and other products, both international brands as well as their own brands), supermarkets (that sell own-brand garment items usually of lower quality), discount stores and mail-order outlets. Few retailers undertake their own production, instead sourcing either directly, or through traders, from developing-country suppliers. Many first-tier suppliers are large regional producers, often based in Hong Kong, who distribute production to their own facilities across a range of countries. Some producers also subcontract to second- and even third-tier suppliers. Thus, there can be an extensive chain between final retailers and actual producers. Yet, the key value-added functions of garment design and marketing rest with the lead firms, the retailers.

There are some significant changes at the retail end that impact on local suppliers. First, there is evidence that, in the face of growing competitive pressures, retailers at the higher quality end (specialist multiples and to some extent department stores) are moving to shorter season product lines. The traditional four seasons are being replaced with multiple seasons, often in line with specialist needs (for example, a 'return to school' line in children's wear as a subcategory of each season). Retailers are keen to keep product shelf lives short and attract consumers with ever-changing fashions. This implies designing new products, in smaller batches, more flexibly and more rapidly. To meet such demands, suppliers must respond rapidly to retail designers in producing samples, re-jigging production lines and meeting shorter delivery schedules. At the same time quality pressures are increasing while unit prices of clothing fall. Most department stores, supermarkets and discount 
outlets are producing cheaper own-brand items that are proving increasingly competitive alongside higher quality, and more expensive, international brands. In the process suppliers are squeezed, having to improve efficiency in order to lower costs while retaining or enhancing product quality.

\section{VIETNAM'S TEXTILES AND GARMENT INDUSTRY}

Garments and textiles - with garments predominating - are Vietnam's largest manufacturing export, generating 16.5 per cent of total export earnings in 2002 (World Bank Vietnam 2003: Table 3.2). Other major manufactured exports include footwear and electronic products. $T \& G$ exports have grown even more rapidly than Vietnam's total exports, with an average rate of 29 per cent annually from 1991 to 2000 (compared to 23 per cent for all merchandise exports). ${ }^{2}$ The garment industry in Vietnam is highly export-oriented, while final sales of Vietnamese textiles are mainly to the domestic market.

The share of textiles in total textiles and garment exports was under 12 per cent by 1998 (Thoburn et al. 2003), ${ }^{3}$ and 94 per cent of T\&G sales to the US in 2002 were of garments. ${ }^{4}$ In the 1996 input-output table, only 11.3 per cent of total gross textile output was directly exported, compared to 84 per cent of total garment production. However, state-owned enterprises (SOEs) producing textiles and exporting about a third of their output, do so mainly by exporting those textiles indirectly, in the form of garments (Thoburn et al. 2003). While textile imports were the equivalent of 77 per cent of gross textile output, clothing imports were the equivalent of 21.8 per cent of the gross output of clothing, indicating the importance of imported textiles for export garment production (see Hill 2000; Vu et al. 2001b).

As Table 1 shows, state-owned enterprises remain important, particularly in textile production. The household sector's share both in garments and textiles has declined considerably, while foreign investors generate over a quarter of output in both sectors. Note, however, that difficulties with the recording of garment output are likely to understate the share of the foreign sector in garment production. ${ }^{5}$

The strong presence of foreign investors in the textile sector reflects the importance of joint ventures between foreign investors and textile SOEs, producing clothing from their own textiles, and the entry of investors from Taiwan and Korea as independent textile producers. As Nadvi and Thoburn (2004) have shown, textile SOEs have been substantially reformed since the early 1990s and in some cases earlier, and have greatly reduced their workforce, while Vietnam's garments workforce has risen despite increases in labour productivity.

\section{FAGING GLOBAL GHALLENGES: HOW DO VIETNAMESE FIRMS RESPOND?}

Garment and textile manufacturers in developing countries are confronting the challenges of changing trade regimes with the phase out of the MFA, competition 
Table 1 Garment and textile output in Vietnam by ownership (per cent)

\begin{tabular}{lrrrrr}
\hline & \multicolumn{2}{l}{ Garments } & & \multicolumn{2}{l}{ Textiles } \\
\cline { 2 - 3 } \cline { 5 - 6 } \cline { 5 - 6 } & 1995 & 2001 & & 1995 & 2001 \\
\hline State sector & 34.8 & 31.7 & & 56.8 & 48.5 \\
$\quad$ Central state sector & 13.2 & 15.6 & & 43.6 & 38.1 \\
$\quad$ Local state sector & 21.6 & 16.1 & & 13.2 & 10.4 \\
Non-state domestic sector & 47.1 & 43.2 & & 25.9 & 23.3 \\
Collective sector & 0.3 & 0.6 & & 1.8 & 1.6 \\
Private sector & 1.6 & 1.2 & & 1.5 & 1.2 \\
Household sector & 35.7 & 21.9 & & 21.6 & 12.8 \\
$\quad$ Mixed economic sector & 9.4 & 14.0 & & 1.0 & 4.7 \\
Foreign-invested sector & 18.2 & 25.1 & & 17.3 & 28.2 \\
Total & 100.0 & 100.0 & & 100.0 & 100.0 \\
\hline
\end{tabular}

Source: GSO (2001), from outputs at constant 1994 prices.

from China, pressures to meet global process standards, and demands from global buyers to reduce lead times, lower costs and raise quality. How have Vietnamese firms responded to such challenges? What are the consequences for Vietnamese firms and workers? We discuss each challenge separately.

\section{(a) Changing international trade regimes ${ }^{6}$}

Textiles and garments are affected by the international regulatory regime of the MFA which restricts entry into the leading global markets, such as the US and the EU, through export quotas administered in the exporting countries. It has been a way in which new exporting countries with as yet unused export quotas could attract foreign investors into garment and textile production, while restricting established exporters like China. The phase out of the MFA by the end of 2004 poses a potential threat to countries whose garment exports have grown on 'quota rents'.

While Vietnam is a recent entrant into the global garment markets, its exports are only partially regulated by the MFA. Exports to Japan are outside the purview of the MFA with Japan being a non-quota market. The EU is different. Vietnam's 1992 trade agreement with the EU gave it preferential garment quotas for the EU market. This explains much of Vietnam's phenomenal export growth to the EU. The phase out will have consequences for Vietnam's quotas in the EU and does, therefore, pose a challenge. Finally, Vietnam has, until recently, only limited exposure to the US market - the leading MFA regulated market. In 1996, 85 per cent of Vietnam's garment exports were to the EU and Japan, equally divided between the two markets. Only 2 per cent were to the US, much lower than the share for its Asian competitors (Hill 2000: 289). 
Vietnam signed a bilateral trade agreement with the US in July 2000 (USBTA) that gave it greatly improved market access, cutting the average tariff facing all Vietnamese exports from about 35 per cent to 5 per cent (World Bank Vietnam 2001b: 27). For T\&G firms the impact is greater still. Since Vietnam is not yet a member of the WTO, Vietnam's garment exports to the US prior to the USBTA faced significantly higher tariffs than those faced by, for example, South African exporters prior to AGOA. ${ }^{7}$ Average tariffs in the US which were around 60 per cent for garments are being cut to around 5 per cent. ${ }^{8}$ Critically, unlike the EU agreement, the USBTA did not initially impose MFA quotas on textile and garment imports into the US. ${ }^{9}$ Among our interviewees, there were divergent views on the effect quotas would have. The buyer for one well-known US retailer commented: 'Vietnam is likely to be a short-term player in the garment market. Its export growth will stop once the US imposes quotas' (interview, Hong Kong, 27 May 2002). A number of other global buyers, however, reported their interest in raising production from Vietnam prior to any imposition of quotas by the US. The premise being the higher the levels of output, the larger the quotas they (or their Vietnamese suppliers) will obtain. Given secondary markets for quotas in quota-constrained countries there were obvious grounds for pursuing such an expansion.

In the event, Vietnam's garment and textile exports to the US increased rapidly - astonishingly - after the signing of the USBTA. ${ }^{10}$ They were US $\$ 49$ million in 2001 and US $\$ 952$ million in 2002. ${ }^{11}$ Quotas were introduced on 1 May 2003. ${ }^{12}$ Even after the quota imposition, Vietnamese T\&G exports to the US rose from US $\$ 1.69$ billion for the twelve months ending April 2003 to US $\$ 2.048$ billion for the twelve months ending June $2003,{ }^{13}$ the rise after the quotas reflecting orders approved prior to the quotas imposition and a rush to export before quotas became effective. Many quota categories were expected by producers to be closed out before the end of the year 2003, ${ }^{14}$ and press reports indicated buyers looking to other countries in the region. ${ }^{15}$

There are doubts that the MFA phase out will result in a full liberalization of garment trade. Few people in the international textile and garment industries believe that the MFA will not be replaced by other export restrictions, especially bilateral and regional preferential agreements. Many global buyers stated that it would be felt unacceptable for China to be allowed to sweep the board in the US and other markets. Anti-dumping measures would be resorted to. In the case of the US, there is an existing agreement that places restrictions on imports from China of textiles and garments until 2008.

Vietnam appears somewhat better positioned than countries like Bangladesh regarding the loss of quota markets under the MFA. Its competitiveness in the Japanese market shows clearly that Vietnamese firms can operate in a quota-free environment and retain market share. Under the USBTA, with initially quota-free access to the US market, leading US buyers sourced heavily from Vietnam to exploit its quota-free position. These patterns are borne out by interviews 
conducted with thirty Vietnamese garment manufacturers (these firms did not produce textiles) ${ }^{16}$ Of the thirty, only one firm reported sales to the US in 1997 , whereas by 2002 thirteen firms were selling in the US market, and seven of these considered the US as their leading export market. Of the remaining twenty-three firms, five considered the EU their leading market, four stated it was Japan, and eight firms cited countries within the region (Korea, Taiwan and Singapore). Most importantly, however, with the exception of smaller private firms, none was wholly dependent on one export market. Thus, while sixteen firms exported to the quota-controlled EU market, the vast majority had a diversified export portfolio.

However, there is little doubt that Vietnam's present advantage in international markets may be temporary. Buyers' decisions on international sourcing are strongly driven by a combination of searching for lower wage costs and gaining access to export quotas to the US and the EU markets. Once MFA quotas are phased out, Vietnam loses its current advantages. Vietnamese firms exporting to the EU lose an advantage against China of not paying a domestic premium to obtain MFA export quotas (only 25 per cent of Vietnam's quotas are auctioned officially) though there were signs of an unofficial market in quotas to the US developing in 2003. ${ }^{17}$ Currently in China, for some 'hot' quota items like men's dress shirts, the cost for an exporter of obtaining a quota can be as high as the cost of manufacture. ${ }^{18}$ Thus, as one leading British buyer located in Hong Kong put it: 'From Vietnam we source only quota-sensitive items. Otherwise why go there? The quality of Vietnamese garments is acceptable, but the price is not so good'.

\section{(b) Competition from Ghina}

If the direct threat of the MFA phase out is in some measure muted for Vietnamese T\&G firms, competition from China is having, and can post-MFA have, a severe impact. These concerns are very much on the mind of Vietnamese producers. Of the thirty garment firms surveyed in 2002, twenty-six saw competition from China as a significant threat. Competition from China has three distinct aspects to it. First, how do Vietnamese costs, especially labour costs, compare with China? Second, given that China has a large domestic textiles industry, how do linkages with the domestic textile sector compare between China and Vietnam? Third, and possibly most important, how do buyers view sourcing decisions on China and Vietnam?

Vietnam's wage rates, at least in the state-owned sector, are from our evidence below those of China. ${ }^{19}$ The average monthly wage for a group of key textile and garment SOEs located in Ho Chi Minh City was US\$98 in the year $2000 .{ }^{20}$ Our figures from the thirty garment firms interviewed in 2002 suggest a much lower figure for average monthly wages of US $\$ 56$. This varied sharply by firm type, from a low of US $\$ 47.50$ per month as average wages in private sector firms to a high of US\$75 a month as wage rates in SOEs. In contrast, average monthly wages in three Hong Kong-owned garment enterprises visited in China in May/ 
June 2002 ranged from around US $\$ 105$ (RMB 870) in a factory in the region around Shanghai, to US\$132 (RMB 1,100) in the Shenzhen special economic zone (where wages are known to be higher). Although this is small sample evidence, competition for workers tends to impose some uniformity of wages in a particular region. More interestingly, a common pattern is that the workforce is dominated by migrants from other provinces, some as distant as Sichuan, since local workers could not be found to work for such wages. ${ }^{21}$ To keep wages low there is a tendency for foreign firms to locate new production away from the south (particularly Guangdong) to further north, particularly the regions outside Shanghai, where also the bulk of China's textile production is located. ${ }^{22}$

Despite the evidence on relative wage costs being ambiguous, ${ }^{23}$ both SOEs and private firms in Vietnam voiced concerns that in their view Chinese wages were lower. Similarly, a number of leading global buyers are emphatic that China is currently the more cost-efficient supplier. China's advantage also extends to fabrics. Hong Kong interviewees commented on the progress made in the Chinese textile industry in recent years. ${ }^{24}$ One leading international trader based in Shanghai said that fifteen years ago Hong Kong-owned firms in the south of China were much better than Chinese ones, but now Chinese textile mills had invested in advanced equipment, for printing and dyeing. Thus, this firm was about to source 75 per cent of its fabric requirements in China, mainly from domestic enterprises. While many noted that China was stronger on cotton fabrics than synthetics, Chinese synthetics were much improved. A leading US buyer based in China was already sourcing 30 per cent of the fabric for their garments within China and expected this proportion to increase to 50 per cent or even 80 per cent within a few years.

Pressure from garment retailers in the industrial countries for shorter lead times provides a stimulus to source locally. The improvements in Chinese textile quality also improve Chinese enterprises' strength as prospective exporters and competitors against Vietnamese fabric both in Vietnam and in third markets. Chinese fabric exporters also find it easier to secure China's 17 per cent export 'subsidy' (rebate on taxes) if they export directly rather than indirectly in garments. Chinese competitiveness in textiles is strengthened by reforms carried out in Chinese SOEs. ${ }^{25}$

Given the competition from the textiles segment of the Chinese T\&G industry, Vietnamese textile firms are responding through new investment. Textiles SOEs, seeking to improve the quality of fabrics produced, have been helped by their privileged access to investment funds to replace obsolete equipment. From 1996 to 2000 enterprises within Vinatex - the state organization in charge of textile and garment SOEs - invested VND 3,504 billion, about US $\$ 230$. Over the five years to 2005, investment equivalent to another US $\$ 2.3$ billion is planned for Vietnam's overall garment and textile sector (of which Vinatex will invest the equivalent of US $\$ 830$ million). The equivalent of another US $\$ 2$ billion will be invested in the five years to 2010, of which Vinatex's investment will be about US\$630 million. ${ }^{26}$ 
To put these sums into perspective, they compare to the value of Vietnam's gross exports of textiles and garments in 2000 of nearly US $\$ 2$ billion. With this investment, the plan envisages local content of garment exports rising from 25 per cent in 2000, to 50 per cent in 2005, and to 75 per cent in 2010.

Our interviews suggest that new investment has been used selectively by enterprises to develop new specialisms or strengthen existing ones. Often this has been in preparation for attempts to export to the United States, such as purchasing dyeing and finishing equipment to produce higher quality fabrics. One large, fully integrated, textile and garment SOE in Ho Chi Minh City, employing 3,000 people with an annual turnover of US $\$ 40$ million, had completely revamped its spinning, weaving, knitting and dyeing plants with new equipment from Japan. It had done so to compete more effectively against China and attract US buyers. The firm, which was in the process of being corporatized, had achieved this through state-subsidized credit. The US now accounted for some 30-40 per cent of its exports, up from nothing five years ago, and productivity had improved. At an aggregate level, the increase in gross labour productivity from investment in textiles was striking - rising 2.5-fold over the 1990s. Yet, there were sharp differences in labour productivity by type of firms (Vu et al. 2001b: 19).

Finally, how do buyers view their sourcing decisions, especially vis-à-vis China? Our interviews suggest a nuanced picture - one in which global buyers have, over the past two decades, actively encouraged first-tier (often Hong Kong-based) garment suppliers to develop production capacity in southern China. Yet wage rates in China are rising, fuelling investment in plants further north in China where wage levels are lower. Despite the MFA phase out, prospects of continued trade regulations remain. Quotas are seen as a political as much as an economic tool, and US policy regarding Chinese imports remains unclear. This leads to caution, as one buyer stated, in referring to sourcing from China, 'You don't want to put all your eggs in one basket'. In his view, while Chinese suppliers outperformed Vietnamese garment firms on response time, flexibility in dealing with large and small orders, and in supplying their own fabrics, sourcing would continue to remain diversified. Thus, while China supplied 15 per cent of this firm's total annual garment purchases of US $\$ 3.7$ billion f.o.b., it would continue distributing 35 per cent of its sourcing between India, the Philippines, Indonesia and Bangladesh. A major shift in attitude with respect to China may emerge when such buyers begin viewing China as an end-market. Currently, the leading international players in Chinese garment retailing are branded Hong Kong-based garment producers.

\section{(c) Labour standards}

Labour standards increasingly matter in the global garment and textiles industry. Driven by consumer pressures and the campaigns of selected international NGOs, compliance with labour standards is now a critical aspect of competing in the US 
and EU markets. But, markets vary. Thus, our Vietnamese firm respondents stated that while compliance with labour standards was not an issue for supplying to Japan, Japanese buyers were especially concerned with overall quality and product detailing. In the EU, labour standards (and, in some cases, environmental standards associated with dyeing) did matter, but that European buyers were more likely to emphasize quality concerns in their discussions with Vietnamese suppliers. On the other hand, for US buyers compliance was often of paramount concern, followed by price and delivery schedules.

While a number of sector-specific labour standards have emerged, most Vietnamese T\&G firms had to comply with the individual company codes of their buyers and final retailers. In most cases, these require suppliers to meet national labour laws. In some cases, codes are framed on the ILO's core labour standards, which address issues of freedom of association, forced labour, non-discrimination and child labour. In addition, some firms are attempting to put in place the SA 8000 code on social standards. SA 8000 is an attempt to harmonize social and labour standards, with an independent system of auditing. Its monitoring procedures borrow from the more widely known, independently audited, ISO 9000 standards on quality assurance which emphasizes documentation for traceability purposes. ${ }^{27}$

Standards do matter to local firms. Of the thirty garment manufacturers surveyed, ten had obtained the ISO 9000 quality standards. This was especially high among centrally controlled SOEs and those SOEs that are in the process of being corporatized. Eight of the nine such firms in the sample had the certificate. Some of these firms stated that ISO 9000 helped improve their management systems and they hoped it would help attract new buyers. Another standards strategy adopted by a number of firms, especially SOEs, was to begin implementation of SA 8000, the international social accountability standard. In the view of many firms, standards were clearly considered as significant for US buyers, implementation of labour standards considered as necessary preparation for exports to the US market. In this process, SOEs and larger firms were much better placed as they already complied with Vietnam's fairly stringent national labour laws. SOEs had the resources to ensure necessary investments regarding compliance. One Hanoi-based SOE which had been corporatized had obtained ISO 9000 and had applied for SA 8000 certification. It felt its quality assurance standard made it more attractive to buyers, and it was well positioned to meet many labour standards concerns thanks to its new, spacious, greenfield production site on the outskirts of the city.

Where compliance issues are a concern is for smaller private garment producers. Many such firms interviewed in both Hanoi and HCMC were struggling to meet some of the stipulations in company codes. In particular, those on health and safety concerns which often required new plant layouts, or in some cases new factory premises. Many small private firms operated in cramped and poorly ventilated premises, often without adequate safety measures. Consequently, 
smaller firms tended to export to markets where concerns on labour standards were less paramount, and/or through smaller regional traders in Taiwan and Korea. Thus, the implementation of standards beyond Vietnamese SOEs and large first-tier suppliers remains a concern for the industry as a whole. In contrast to the views of firms in Vietnam, interviews with US and EU buyers suggested that standards compliance concerns were never as high as concerns about a supplier's price, quality and delivery reliability. In the view of these buyers, standards compliance were a necessary but far from sufficient basis for selecting suppliers. As some said, meeting compliance requirements was not difficult. First, individual company codes were very similar, and if a supplier met one company's code it was more than likely to be able to comply with that of another buyer. Second, given that many such buyers largely sourced, either directly or indirectly, from Vietnamese SOEs, compliance was not considered a significant constraint for such producers.

The demands from buyers for better quality, lower price and faster delivery points to an important contradiction with the needs for meeting global standards. Many firms in Vietnam, especially SOEs, stated that buyers' codes that restricted overtime had to be balanced with demands from the same buyers for shorter lead times. Meeting delivery schedules was critical to retaining orders. In some cases, this meant that standards had to be interpreted 'flexibly'. ${ }^{28}$ These pressures underline the demands of the new competition within the global garment industry.

\section{(d) New competitive pressures}

The global garment industry is being increasingly influenced by changes taking place at the retail end. There is both a process of increasing concentration, especially as many traditional garment retailers struggle to compete in more price-competitive markets. There is also the entry of a variety of new types of retailers. These include the aggressive entry of supermarkets and discount outlets in garment retailing as well as the growth of new specialist multiples that targeted the large youth market with low priced but high quality, design-intensive, products. To succeed these retailers promoted high shelf turnover, with as one US buyer stating their traditional four seasons a year product cycles being replaced by a sixteen seasons cycle. Another retailer was said to be aiming for a fifty-two seasons cycle, with new product lines every week. This required rapid delivery as well as consistent high quality and low prices on the part of suppliers. Some retailers had turned towards integrating production as one way to reduce lead times and ensure quality and scale economies. One of the leading new European retailers had set up its own integrated garment manufacturing facility in its native Spain to bring lead times down for certain high-volume items to forty-eight hours. This contrasts with average lead times from Vietnam of at least four to six weeks. 
These pressures were clearly felt by Vietnamese suppliers. Twelve of the thirty garment firms interviewed stated that unit prices had fallen in the past five years. ${ }^{29}$ This was especially so for SOEs, many of whom had on entering the US market found it to be more price competitive than either the Japanese or EU markets. One SOE in HCMC, with an annual turnover of US\$28 million and supplying both US and EU buyers, stated while output had increased three-fold in the past three years, unit prices had on average declined by 20 per cent, and in some products by 40 per cent. US buyers were seen as being especially aggressive in forcing prices down. An extreme form of this, according to a leading US buyer, was the practice adopted by a large US supermarket chain to use Internet-based auctions as a basis for forcing price competition among their suppliers.

In addition to price pressures delivery schedules also mattered. Twenty-eight of the thirty firms interviewed felt that meeting delivery times was now as critically important as product quality. Again this varied by types of buyers. As one leading SOE shirt exporter in Hanoi stated, 'EU buyers don't care so much about labour standards - they focus on quality. EU buyers are also more flexible on delivery and will accept small delays. US buyers are more stringent on delivery dates and on labour overtime issues' (interview, Hanoi, 17 April 2002). In addition, there were quite distinct sourcing patterns across buyers. US buyers, for example, placed orders for much larger batch sizes than those in Japan and the EU. Thus while it was not uncommon for US batch sizes to be in the order of 100,000 pieces for shirts, in the Japanese market batch sizes could be as small as 5,000 pieces.

The only possible option for $T \& G$ suppliers in response to these pressures is to upgrade. They need to raise efficiency (process upgrading), improve products (product upgrading) and/or the tasks that they do (functional upgrading). Some international Hong Kong garment producers - something of a model for international best practice - are engaging in process upgrading by adopting cellular manufacturing systems. Many are improving their supply-chain management and their design capabilities. Design capabilities also strengthen prospects for product upgrading. In this sense, the best-practice frontier, at which Vietnam needs to aim, is moving outwards. Foreign investors in garment exports and textiles have their parent companies to help them upgrade, but their efficiency is reduced by deficiencies and high costs in Vietnam's telecommunications, transport and power supplies. Vietnamese textile SOEs exporting garments have tended to aim at low-end markets and at niche markets where dyeing quality is not a problem. While this cannot be criticized as a starting point, obviously more process and product upgrading is necessary. The tendency of garment companies to engage in CMT work is sometimes supported since it reduces garment producers' risks; such producers are not required to find markets, nor to carry the costs of acquiring fabrics (Goto 2002). However, CMT work offers limited scope for upgrading, and continued reliance on it increases vulnerability. 


\section{GONGLUSIONS}

This paper set out to assess how globalization has affected the Vietnamese textile and garments industry. Vietnam has emerged during the 1990s as a significant garment supplier to quality-conscious markets in the EU, Japan and now the US. But, like developing-country garment and textile producers world-wide, its continued success depends on its ability to successfully confront the challenges currently shaping the global garment and textiles industry. While Vietnam as a whole has done well, the gains from engagement in global markets are differentially distributed. Thus, in facing global challenges, there are clear winners and losers, at the level of firms and of workers. In this concluding section, we focus on this differentiated story - distinguishing between winners and losers at the level of sectors - garments and textiles, firms - SOEs and private enterprises, and workers - by gender, education and location.

Vietnam's export garment sector has grown more rapidly in recent years than its textile industry. It has done so largely with imported fabrics. CMT production has meant that fabric sourcing remains in the purview of buyers. But competitive pressures from China, demands from buyers to reduce lead times and the Vietnamese government's aim to raise local content in garment exports implies greater efforts are required in developing the textile industry to meet the needs of the export garment sector. Many T\&G SOEs point the way forward in this, through investments in textile spinning, weaving and dyeing. But this has been done with subsidized state credit unavailable to the private sector.

Another aspect of the winners and losers is the ability of large SOEs to be able to insert themselves into the value chains of leading global buyers. SOEs are able to take on large orders, to manufacture a relatively diverse product range, and to easily meet demands on compliance with global standards. Thus, there are clear signs that while the numbers of private garment firms are expanding, especially in the south, such producers face greater difficulties in accessing higher quality and higher value chains. Small private firms often supply smaller regional traders, operate in poorer working conditions, pay lower wages and employ more relatively more marginalized workers.

Gains are also differentially felt at the level of workers. The bulk of the Vietnamese garment and textile labour force consists of women workers. Women workers are especially significant in the rapidly growing garment subsector, where they often account for up to 80 per cent of the total labour force in individual factories. While women workers have gained, both in terms of increasing employment opportunities and rising wages, those who work for the larger SOEs and for FDI units have fared better. A separate study by Kabeer and Tran (2003) found higher average wage levels, and better working conditions, for women garment workers working in private joint-venture units and in SOEs and lower for those in the private and cooperative segment of garment manufacture. Access to waged work in SOEs is dependent on attaining a minimum educational qualification of a 
high school certificate and having residency status within the region or urban centre in which the SOE is located. This implies that migrant women workers, especially from the poorer northeastern provinces and from the central highlands, are unlikely to access better paid SOE jobs as they will rarely have the requisite residency status or the necessary level of formal schooling. Furthermore, within textiles and garments units there is a clear gender-based division of labour with women workers being excluded from more highly remunerated and technically skilled tasks on the grounds that such work requires the heavier labour of men (see Kabeer and Tran 2003; Nguyen et al. 2003).

Vietnam's textiles and garment industry remains a critical element of the country's ambitious export-led growth strategy. The nature of global challenges that currently shape the garments and textiles industry pose significant pressures on local producers, and call for attempts to upgrade in order to improve quality, lower price and reduce delivery times in order to meet the demands of global buyers within highly orchestrated global value chains. To this is added the need to comply with codes of conduct addressing labour and environmental standards, confront competition from neighbouring China and to prepare for emergent changes in the global trade regimes that govern international trade in garments and textiles. It is apparent that many Vietnamese producers, especially large SOEs that have entered into export garment production and foreign-invested and joint-venture units, are well placed to face such challenges. However, the pressures on smaller private firms are more acute, and their ability to access the higher value-added aspects of the global chain more doubtful. Similarly, the gains from engagement in such global markets are distributed unevenly amongst workers. While women workers as a whole have benefited, those with residency status and educational qualifications are likely to fare better in the new competition.

Institute of Development Studies, University of Sussex, Brighton, UK

School of Development Studies, University of East Anglia, Norwich, UK

\section{ACKNOWLEDGEMENTS}

This paper has been prepared as part of the project 'Globalization, Production and Poverty' (R7623), financed by a research grant from the UK Department for International Development. Vietnam is one of two target countries in which the impact of globalization has been studied in relation to the textiles industry; the other is South Africa. Garments have been studied in Vietnam and Bangladesh. For more information on the project, see http://www.gapresearch.org/production/ globprodpov.html. The UK Department for International Development (Df ID) supports policies, programmes and projects to promote international development. Df ID provided funds for this study as part of that objective, but the views 
and opinions expressed are those of the authors alone. We are especially grateful to respondents interviewed in Vietnam, Hong Kong, China and the UK, and to Gary Gereffi, John Humphrey, Myriam Velia and a referee for comments on earlier versions of the paper. The usual disclaimer applies.

\section{NOTES}

1 See http://www.mof.go.jp/english/1c015fle.htm for Japanese data, and for EU data see Eurostat http://dataweb.usitc.gov/scripts/user_set.asp.

2 Least squares growth rates in current US dollars calculated from data in World Bank Vietnam (1998, 2001b), deflated into constant dollars by index of (dollar) export unit values of industrial countries (from IMF, International Financial Statistics, various issues) to indicate the real purchasing power of Vietnam's exports. In fact, the deflation makes almost no difference to the growth rates, as the export unit values for industrial countries fell almost imperceptibly over the period, with a trend not significantly different from zero. Start-year 1991 rather than 1990 is used since textile and garment exports were starting from a very low base in 1990, thus exaggerating their growth rate.

3 This compares to the share of textiles in total world textile and garment exports of 43 per cent (WTO 2002), and is low in comparison to other Asian countries (Hill 2000).

4 See http://otexa.ita.doc.gov.

5 This is because processing fees are often recorded as 'output' where firms are engaged in export production based on processing imported fabrics. Such problems do not arise for household production - catering mainly to the domestic market - and more state-owned enterprises in garments are vertically integrated from textiles to garments. This issue is discussed further in Thoburn et al. (2003).

6 In addition, Vietnam has introduced significant domestic trade reforms. For summaries on these see CIE (1998: 5-8); Martin (2001: 17-25); Vu et al. (2001a); World Bank Vietnam (2001a, 2001b: 86-8); and IMF (2002: 38-53).

7 South African garment exporters to the US faced tariffs of an average of about 17 per cent before the Africa Growth and Opportunity Act. AGOA, which came into effect in 2001, gives African countries duty-free access for garments into the US, though with strict stipulations on local content (see Roberts and Thoburn 2003).

8 There is much variation in the tariff cuts by product. For example, the US tariff on imports of women's underwear is cut from 60 per cent to zero, while that on men's cotton shirts is reduced from 45 per cent to 20.4 per cent (www.business-in-asia.com/ vn_portland3.htm).

9 For discussion of the USBTA in relation to textiles and garments, see Manyin (2001: 9).

10 One puzzling aspect of this expansion, which has occurred since our fieldwork in 2001 , is that a subsidy from the Vietnamese government for textile (presumably including garment) companies exporting to the US, equivalent to 7 per cent of export sales value, was announced in January 2002 (see, for example, Sayres 2002: 6). In fact, according to a contact in Hong Kong with garment production in Vietnam, this subsidy was never implemented and the idea has been quietly dropped (private communication, 8 January 2004).

11 Of course, some of these exports may be illegal transshipments of garments produced elsewhere that have escaped US surveillance procedures.

12 As part of the new US-Vietnam textile agreement, under which the quotas are given, Vietnam agrees to comply with the International Labour Office and support implementation of codes of corporate social responsibility (www.ustr.gov/regions/ asia-pacific/2003-04-25-Vietnam-textiles-summary.pdf). For a discussion of this issue 
in relation to the imposition of labour standards on Cambodia under the 1999 US-Cambodia agreement, see Abrami (2003) and Sayres (2002).

13 http://www.otexa.ita.doc.gov.

14 Private communication from a Hong Kong garment manufacturer, 3 September 2003.

15 See Far Eastern Economic Reviere, 7 August 2003, p. 8.

16 Of the thirty firms, thirteen were private enterprises, five SOEs, four joint-stock companies (SOEs that were being formally restructured and 'privatized'), two joint ventures (SOEs with some foreign investment) and six fully foreign-invested firms. Eleven were Hanoi based and nineteen were in Ho Chi Minh City.

17 Private communication from Hong Kong garment manufacturer, 3 September 2003. Presumably there is also unofficial trading of quotas into the EU.

18 In China, apparently about a quarter of China's textile export quotas are auctioned officially by MOFTEC, the Ministry of Foreign Trade and Economic Cooperation, but there is much wider unofficial trading of quotas (interviews, Shanghai and Beijing, May/June 2002).

19 This can be compared to the average wage payments in manufacturing industry as a whole of US\$711 per year in Vietnam and US\$729 in China for the period 1995-99 given in World Bank (2002: Table 2.5).

20 This is data drawn from enterprise annual reports. Note that wages in Hanoi tend to be somewhat lower than in HCMC (Nguyen et al. 2003). HCMC and Hanoi are Vietnam's two main centres of textile and garment production.

21 A similar migration pattern is seen in Vietnam, especially in small private sector firms in HCMC. Here, migrant workers (who often work and live in the same premises) come mainly from the poorer central highlands and to a lesser degree from northeastern provinces.

22 The main textile and garment provinces, accounting for about 70 per cent of China's output, are Guangdong, Shanghai, Zhejiang, Jiangsu and Shandong (see HKTDC 2001: 2). Zhejiang and Jiangsu are the provinces nearest to Shanghai.

23 Relative wage costs are relative wage rates adjusted for labour productivity differences, sometimes known as unit labour costs. UNCTAD's (2002: 158) short study of the Chinese textile and garment industry notes that data on unit labour costs are not available at the sectoral level. But even if they were available, average sectoral figures would conceal the fact that the export-oriented parts of the Chinese $T \& G$ industry are much more competitive than the sectoral average. We were unable to collect relative productivity data, but it is very likely that Chinese labour productivity in garments and textiles will be higher than in Vietnam as a result of China's longer experience in these industries. So if Vietnamese wage rates approach those of China, it is likely that Vietnamese wage costs will rise above the Chinese level. Jenkins's paper in this issue (Table 6) notes that in 2000 average labour productivity in Chinese manufacturing (measured in US dollars in terms of total value added per worker) was almost 2.5 times higher than in Vietnam.

24 Indeed, the textile industry in China has been one of the pioneers of the Chinese industrial reform programme since the late 1970s. See Moore (2002: Ch. 5).

25 For example, the Shanghai Industrial Company, with 100 textile mills, many of them loss-making, was given over to another corporation to turn them around and reorganize them into an enterprise group; while in Zhejiang, all textile SOEs had apparently been privatized. These comments are based on interviews in the Shanghai region by Thoburn in June 2002.

26 Vinatex is concentrating its investment on ten focal textile industrial zones. There will be four zones in northern Vietnam, two zones in central Vietnam and four zones in southern Vietnam. Each zone will operate as an interlinked cluster with a spinning factory, a light fabric-weaving factory, a heavy fabric-weaving factory, a dyeing and 
finishing factory for cotton fabrics, a weaving-finishing factory for synthetics, a factory for knitting, dyeing, finishing and making garments; and a sewage processing factory to ensure compliance with environmental standards.

27 For an overview of the leading sectoral and cross-sectoral standards - such as the Clean Clothes Campaign, US Fair Labor Association, ISO 9000 and SA 8000 - and of the trajectory of global standards, see Nadvi and Wältring (2004).

28 Hong Kong garment firms operating in China also stressed the contradiction between limitations on overtime and requirements for rapid delivery.

29 This has to be seen in the context of a general decline in the import unit values both for garments and for textiles into the US and the EU-15 during the 1990s (see Edwards 2003: Table 2.13, using data from www.itcb.org). However, Nadvi and Thoburn (2004) present data analysis showing that in export categories of particular importance to Vietnam in the Japanese and the EU markets, unit values of imports from Vietnam, and Vietnam's market shares, have held up well in relation to those of competitors. Vietnam's exports of T\&G to the US are too recent for a comparison to be made with the EU and Japanese data for the 1990s.

\section{REFERENGES}

Abrami, R. (2003) 'Worker rights and global trade: the US-Cambodia Bilateral Textile Trade Agreement', Harvard Business School Case Study 9-703-034, Cambridge, MA: Harvard University Press.

Bui Xuan Khu (2001) 'Development for Vietnam textile and garment industry', seminar speech on 3 April in Hanoi by General Director of Vinatex (on Vinatex website www.vinatex.com).

CIE (1998) Vietnam's Trade Policies 1998, Canberra and Sydney: Centre for International Economics, January.

CPRGS (2002) The Comprehensive Poverty Reduction and Growth Strategy, Hanoi: Socialist Republic of Vietnam, May.

Edwards, C. B. (2003) 'The end of MFA quotas on textiles and clothing in 2005 - is it likely, and what follows?', draft briefing paper, mimeo, Traidcraft, London.

Gereffi, G. (1999) 'International trade and industrial upgrading in the apparel commodity chain', Fournal of International Economics 48(1): 37-70.

Goto, K. (2002) 'Coordinating risks and creating value: the challenges for the Vietnamese textile and garment industry', mimeo, Japan International Cooperation Agency, Hanoi.

GSO (2000) Analysing the Results of the Industrial Survey of Vietnam - 1999, Hanoi: General Statistics Office of Vietnam, Statistical Publishing House.

GSO (2001) Vietnam Statistical Yearbook 2001, Hanoi: General Statistics Office of Vietnam, Statistical Publishing House.

Hill, H. (2000) 'Export success against the odds: a Vietnamese case study', World Development 28(2): 283-300.

HKTDC (2001) China's WTO Accession: Implications for Hong Kong's Manufacturers / Traders in Textile and Clothing Products, Hong Kong: Hong Kong Trade Development Council, March.

IMF (2002) 'Vietnam: selected issues and statistical appendix', Country Report No. 02/5, International Monetary Fund, Washington, DC.

Kabeer, N. and Tran, T. V. A. (2003) 'Global production, local markets: gender, poverty and export manufacturing in Vietnam', IDS mimeo, Institute of Development Studies, Brighton.

Manyin, M. E. (2001) The Vietnam-US Bilateral Trade Agreement, Washington, DC: Congressional Research Service Report for Congress, June. 
Martin, W. (2001) 'Trade policy reform in the East Asian transition economies', World Bank Policy Research Working Paper No. 2535, January.

Moore, T. G. (2002) China in the World Market: Chinese Industry and International Sources of Reform in the Post-Mao Era, Cambridge: Cambridge University Press.

MPDF (2000) Vietnam's Garment Industry: Moving up the Value Chain, Hanoi: Mekong Project Development Facility.

Nadvi, K. and Thoburn, J. T. (2004) 'Vietnam in the global garment and textile value chain: impacts on firms and workers', Fournal of International Development 16(1): 11-125.

Nadvi, K. and Wältring, F. (2004) 'Making sense of global standards', in H. Schmitz (ed.) Local Enterprises in the Global Economy: Issues of Governance and Upgrading, Cheltenham: Edward Elgar.

Nguyen, T. H., Sutherland, K. and Thoburn, J. T. (2003) 'Globalization and the impact of restructuring in the textiles sector on households in Vietnam', Globalization, Production and Poverty Discussion Paper No. 12 (www.gapresearch.org).

Roberts, S. J. and Thoburn, J. T. (2003) 'Adjusting to trade liberalization: the case of firms in the South African textile sector', Fournal of African Economies 12(1): 74-103.

Sayres, N. J. (2002) The Vietnam-US Textile Agreement Debate: Trade Patterns, Interests and Labour Rights, Congressional Research Service Report for Congress, Washington, DC, June.

Spinanger, D. (1999) 'Textiles beyond the MFA phase-out', The World Economy 22(4): 455-76.

STAR (2003) An Assessment of the Economic Impact of the United States-Vietnam Bilateral Trade Agreement: Annual Economic Report for 2002, Hanoi: Support for Trade Acceleration (STAR) Project, and Central Institute for Economic Management.

Thoburn, J. T., Nguyen Thi Thanh Ha and Nguyen Thi Hoa (2003) 'Globalization and the textile industry of Vietnam', Globalization, Production and Poverty Discussion Paper No. 10 (www.gapresearch.org).

UNCTAD (2002) Trade and Development Report 2002. Geneva: United Nations Conference on Trade and Development.

Vu Quoc Huy, Vi Tri Thanh, Nguyen Thang, Cu Chi Loi, Nguyen Thi Thanh Ha and Nguyen Van Tien (2001a) Trade Liberalization and Competitiveness of Selected Industries in Vietnam Project: An Overview of Vietnam's Trade Policy in the 1990s: The Changes and Impacts, Institute of Economics (Hanoi)/International Development Research Center (Canada), Hanoi, April 2001.

Vu Quoc Huy, Vi Tri Thanh, Nguyen Thang, Cu Chi Loi, Nguyen Thi Thanh Ha and Nguyen Van Tien (2001b) Trade Liberalization and Competitiveness of Selected Industries in Vietnam Project: Textile and Garment Industry in Vietnam, Institute of Economics (Hanoi)/ International Development Research Center (Canada), Hanoi, May 2001.

World Bank (2002) World Development Indicators, 2002, Washington, DC: World Bank.

World Bank Vietnam (1998) Vietnam: Rising to the Challenge: An Economic Report, Hanoi: World Bank Vietnam.

World Bank Vietnam (2000) Vietnam 2010, Entering the 21st Century: Vietnam Development Report, 2001, Pillars of Development, Hanoi: World Bank Vietnam.

World Bank Vietnam (2001a) Taking Stock: An Update on Vietnam's Economic Reforms: Progress, Next Steps and Donor Support, report of mid-year consultative group meeting, Hoi An, 18-19 June 2001.

World Bank Vietnam (2001b) Implementing Reforms for Faster Growth and Poverty Reduction: Vietnam Development Report 2002, Hanoi: World Bank Vietnam.

World Bank Vietnam (2003) Vietnam Development Report 2004. Hanoi (www.worldbank.org.un/ publications/pub-pdf/vietnam\%20development\%20report\%202004.pdf), November.

WTO (2002) International Trade Statistics 2002, Geneva: World Trade Organization (www.wto.org). 